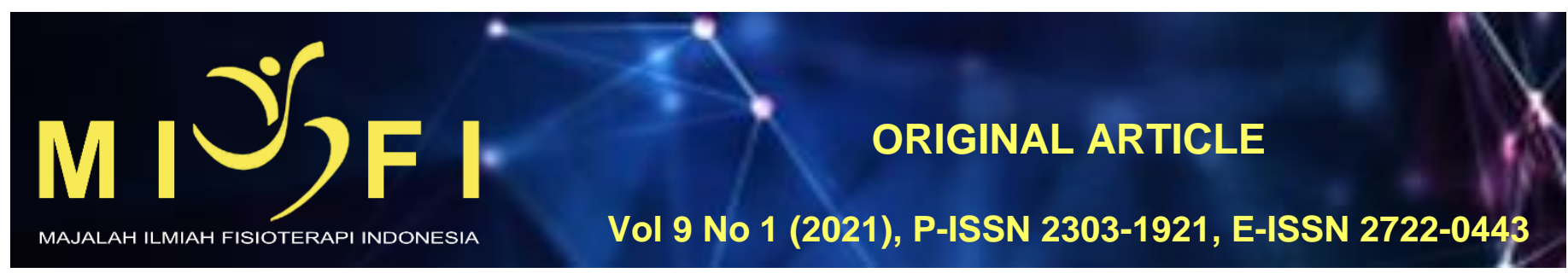

\title{
HUBUNGAN ANTARA KUALITAS TIDUR DENGAN INDEKS MASSA TUBUH PADA MAHASISWA DI FAKULTAS KEDOKTERAN UNIVERSITAS UDAYANA
}

\author{
Ni Dyah Putu Purnamasari ${ }^{1}$, M. Widnyana ${ }^{2}$, Ni Komang Ayu Juni Antari ${ }^{3}$, Ni Luh Nopi Andayani ${ }^{4}$ \\ ${ }_{1}^{1}$ Program Studi Sarjana Fisioterapi dan Profesi Fisioterapi, Fakultas Kedokteran Universitas Udayana, Denpasar,Bali \\ 2,3,4Departemen Fisioterapi, Fakultas Kedokteran Universitas Udayana, Denpasar,Bali \\ purnamasaridyah29@gmail.com
}

\begin{abstract}
ABSTRAK
Mahasiswa merupakan individu dewasa muda yang produktif dan rentan mengalami kekurangan tidur. Kondisi kurang tidur memiliki dampak pada menurunnya konsentrasi belajar pada mahasiswa serta gangguan kesehatan salah satunya obesitas. Obesitas dan kegemukan merupakan masalah kesehatan yang mempertinggi risiko terjadinya penyakit non-infeksi antara lain kardiovaskular, diabetes, atau bahkan penyakit kanker yang menurut WHO memiliki angka kematian dua kali lipat lebih tinggi dari angka kematian akibat penyakit infeksi. Penelitian ini memiliki tujuan yakni mengetahui hubungan antara kualitas tidur dengan indeks massa tubuh pada mahasiswa di Fakultas Kedokteran Universitas Udayana. Rancangan penelitian yang digunakan yakni observasional analytic, menggunakan metode pendekatan studi cross sectional, serta teknik simple random sampling dalam pengambilan sampel. Sampel berjumlah 85 orang, yang dinilai kualitas tidurnya dengan kuesioner Pittsburgh Sleep Quality Index (PSQI) dan Indeks Massa Tubuh (IMT) menggunakan rumus yakni berat badan (satuan kg) dibagi dengan tinggi badan kuadrat (satuan meter). Hipotesis diuji menggunakan uji chi-square dengan tujuan menganalisis hubungan kualitas tidur dengan IMT. Analisis data memperoleh nilai $p=0,000(p<0,05)$, sampel dengan kualitas tidur buruk berjumlah 52 orang $(61,1 \%)$ dan dominan memiliki IMT berlebih (44,7\%), sedangkan 33 orang (38,9\%) tergolong kualitas tidur baik dan dominan memiliki IMT normal (25,9\%). Simpulan yang didapatkan yakni ada hubungan antara kualitas tidur dengan IMT pada mahasiswa di Fakultas Kedokteran Universitas Udayana. Sampel dengan kualitas tidur buruk dominan memiliki IMT berlebih dengan nilai IMT $\geq 25,0$ dan sampel dengan kualitas tidur baik dominan memiliki IMT normal dengan nilai IMT $\geq 18,5-<24,9$.

Kata Kunci: Mahasiswa, Kualitas Tidur, IMT
\end{abstract}

\section{RELATIONSHIP BETWEEN SLEEP QUALITIES WITH BODY MASS INDEX OF MEDICAL FACULTY STUDENTS IN UDAYANA UNIVERSITY}

\begin{abstract}
Students are productive adolescents and vulnerable to sleep deprivation. Sleep deprivation has an impact on decreasing student's learning concentration and health problems, one of which is obesity. Obesity and overweighting are health problems that can increase the incidence of non-infectious diseases such as diabetes mellitus, cardiovascular disease and even cancer, which according to WHO has a double death rate as high as infectious disease. The current study aims to identify the relationship between sleep qualities with body mass index of medical faculty students, Udayana University. This research was an observational analytic and cross-sectional study approach with simple random sampling technique involving 85 students. Data collection was done by measuring sleep quality using the Pittsburgh Sleep Quality Index (PSQI) questionnaire and Body Mass Index or (BMI) with the formula weight (kg) divided by height $\left(\mathrm{m}^{2}\right)$. The hypothesis test used was chi-square to analyze the relationship between sleep qualities and body mass index. Data analysis obtained $p$ value $0.000(p<0.05)$, sample with poor sleep quality were 52 people $(61.1 \%)$ predominantly have overweight BMI (44.7\%), whereas 33 people (38.9\%) belong to the category good sleep quality with predominantly have normal BMI (25.9\%). The conclusions obtained that there is a relationship between sleep quality and BMI in students at the Medical Faculty, Udayana University. Samples with poor sleep quality predominantly have overweight $\mathrm{BMI}$ with $\mathrm{BMI}$ values $\geq 25.0$ and samples with good sleep quality predominantly have normal BMI with BMI values $\geq 18.5-<24.9$.
\end{abstract}

Keyword: Students, Sleep Quality, BMI

\section{PENDAHULUAN}

Tidur merupakan kondisi istirahat yang secara alami dilakukan oleh seluruh makhluk hidup terutama manusia. ${ }^{1}$ Salah satu manfaat yang didapatkan dari tidur yakni sebagai proses pemulihan bagi tubuh sehingga stamina kembali dalam kondisi yang optimal. ${ }^{2}$ Kualitas tidur menunjukkan seberapa individu mampu untuk mempertahankan tidurnya, sehingga kebutuhan terpenuhi dengan jumlah istirahat yang didapatkannya. ${ }^{3}$ Aspek yang terdapat dalam kualitas tidur meliputi aspek subjektif dan kuantitatif. Waktu yang diperlukan hingga tertidur, frekuensi terbangun dari tidur serta lama tidur tegolong dalam aspek kuantitatif, sementara kedalaman serta rasa puas dalam tidur tergolong dalam aspek subjektif dari kualitas tidur. ${ }^{2}$ Mahasiswa merupakan dewasa muda yang produktif dan rentan mengalami kekurangan tidur. Sebanyak 70,6\% mahasiswa dilaporkan memiliki durasi tidur kurang dari delapan jam, yang mana dewasa muda memerlukan waktu tidur yakni sebanyak delapan jam per hari. ${ }^{1}$ Durasi tidur merupakan salah satu komponen dari tujuh 
komponen yang digunakan untuk menilai kualitas tidur, maka dari itu durasi tidur yang singkat dapat mempengaruhi nilai dari kualitas tidur. ${ }^{4}$

Penelitian yang dilakukan Sharma 2018 mendapatkan hasil bahwa mahasiswa kedokteran memiliki kualitas tidur yang buruk dan durasi tidur $<7$ jam daripada mahasiswa non kedokteran. ${ }^{5}$ Kualitas tidur buruk yang dimiliki mahasiswa kedokteran dikaitkan dengan panjangnya durasi pendidikan, intensitas belajar tinggi dan gaya hidup pada mahasiswa kedokteran. ${ }^{6}$ Mahasiswa kedokteran tidak hanya memiliki jadwal akademis yang padat namun juga memiliki jadwal non akademis seperti mengikuti berbagai kegiatan organisasi untuk mengasah soft skill yang dimiliki. Padatnya kegiatan akademis dan non akademis pada mahasiswa kedokteran, menyebabkan semakin beratnya tanggung jawab yang dimiliki oleh mahasiswa kedokteran. Tanggung jawab berat yang dimiliki mahasiswa kedokteran ditambah dengan durasi pendidikan yang panjang akan menyebabkan mahasiswa kedokteran semakin rentan mengalami stres dan kecemasan yang mana hal tersebut akan berdampak pada kualitas tidur mahasiswa. ${ }^{7}$

Studi epidemiologi mendapatkan hasil yakni, terdapat hubungan durasi tidur dan berat badan, durasi tidur singkat dan berkepanjangan bersamaan dengan terjadinya peningkatan berat badan yang dihubungkan dengan berkurangnya tingkat sirkulasi leptin dan peningkatan kadar ghrelin. ${ }^{8}$ Penurunan jam tidur dikaitkan dengan beberapa perubahan fisiologis pada tubuh yakni adanya peningkatan kadar kortisol, peningkatan kadar ghrelin, penurunan sirkulasi leptin serta gangguan metabolisme glukosa. ${ }^{9}$ Ghrelin berperan dalam meningkatkan nafsu makan dan menurunkan pemakaian cadangan lemak. Penurunan jam tidur pada seseorang dapat menyebabkan terstimulasinya ghrelin, sehingga nafsu makan meningkat dan pemakaian cadangan lemak semakin menurun. ${ }^{10}$ Sebaliknya, penurunan jam tidur akan menurunkan kadar leptin yang menyebabkan sulit menghambat nafsu makan dan menurunnya rangsangan pengeluaran energi. Hal ini dikarenakan leptin berperan mengatur massa jaringan lemak dan berat badan dengan cara menghambat asupan makanan dan merangsang pengeluaran energi. ${ }^{11}$

Kualitas tidur buruk juga memiliki dampak pada kondisi fisik seseorang. Seseorang dengan kualitas tidur buruk akan merasakan kelelahan yang menyebabkan diri cenderung mengurangi aktivitas dan olahraga. Kondisi tersebut dapat diperburuk dengan pola hidup yang tidak baik. Berkurangnya aktivitas dan olahraga disertai dengan pola hidup yang tidak baik, dalam jangka waktu panjang akan berdampak pada terjadinya peningkatan indeks massa tubuh yang berujung pada obesitas. ${ }^{12}$ Obesitas dan kegemukan merupakan masalah kesehatan yang dapat mempertinggi risiko terjadinya penyakit non infeksi dengan angka kematian dua kali lipat lebih tinggi dibandingkan dengan penyakit infeksi. Penyakit non infeksi yang dapat terjadi seperti diabetes melitus, penyakit kardiovaskular, bahkan kanker. ${ }^{13}$

\section{METODE}

Rancangan penelitian yang digunakan observasional analytic dengan pendekatan studi cross sectional. Penelitian dilakukan pada bulan April - Juli 2019 pada mahasiswa di Fakultas Kedokteran Universitas Udayana. Sampel berjumlah 85 orang yang didapatkan dengan teknik pengambilan Simple Random Sampling.

Sampel penelitian telah memenuhi kriteria inklusi yakni merupakan mahasiswa aktif angkatan 2017 di Fakultas Kedokteran Universitas Udayana, laki-laki maupun perempuan, usia 17-23 tahun, bersedia menjadi sampel dalam penelitan dengan mengisi informed consent serta tidak termasuk dalam kriteria eksklusi seperti mengalami nyeri, batuk dan sesak nafas yang dapat mengganggu tidur malam dalam satu bulan terakhir serta tidak mengkonsumsi obat tidur selama satu bulan terakhir.

Pada penelitian ini, kualitas tidur merupakan variabel independen sedangkan IMT merupakan variabel dependen. Variabel yang dikontrol dalam penelitian yaitu usia serta yang menjadi variabel rambang penelitian antara lain suara atau tingkat kebisingan, cahaya ruangan, suhu ruangan, pola makan, serta aktivitas fisik.

Penelitian diawali dengan pemberian informasi kepada responden terkait manfaat, tujuan, serta prosedur penelitian yang kemudian dilanjutkan dengan pengisian informed consent dan wawancara terkait umur, riwayat penyakit serta penggunaan obat tidur dalam satu bulan terakhir, kemudian melakukan penilaian kualitas tidur dengan kuesioner PSQI dan pengukuran IMT. Hasil penilaian kualitas tidur terdiri dari dua kategori yakni kualitas tidur baik apabila total skor PSQI > 5 serta kualitas tidur buruk apabila total skor PSQI 0 - 5. Pengukuran IMT pada sampel penelitian dilakukan melalui pengukuran berat badan menggunakan timbangan serta pengukuran tinggi badan menggunakan microtoise, hasil yang didapat dihitung dengan rumus $I M T=B B / T B^{2}$, lalu hasil yang didapatkan kemudian dikategorikan sesuai dengan klasifikasi IMT berdasarkan Depkes RI yakni kurus (underweight) dengan IMT bernilai < 18,5, kategori normal dengan nilai $\geq 18,5-<24,9$, kategori berat badan berlebih (overweight) dengan nilai $\geq 25,0-<27,0$ dan obesitas dengan nilai $\geq 27,0$.

Data penelitian yang diperoleh kemudian dilakukan analisis pada software yakni Statistical Package for the Social Sciences (SPSS). Analisis data pada penelitian ini antara lain univariat yang bertujuan menggambarkan secara umum karakteristik sampel serta analisis bivariat menggunakan chi-square dengan tujuan melihat hubungan antara variabel independen yakni kualitas tidur dan IMT sebagai variabel dependen.

\section{HASIL}

Penelitian ini dilakukan pada mahasiswa angkatan 2017 di Fakultas Kedokteran Universitas Udayana yang berstatus aktif yakni sebanyak 85 orang. Gambaran karakteristik sampel seperti usia, jenis kelamin, kualitas tidur, dan IMT didapatkan dari hasil analisis univariat. Berikut merupakan tabel hasil analisis karakteristik sampel penelitian. 
Tabel 1. Karakteristik Usia Sampel Penelitian

\begin{tabular}{ccc}
\hline Usia & Frekuensi $(\mathrm{n})$ & Persentase $(\%)$ \\
\hline 18 tahun & 1 & 1,2 \\
19 tahun & 27 & 31,8 \\
20 tahun & 55 & 64,7 \\
21 tahun & 2 & 2,4 \\
\hline Total & 85 & 100 \\
\hline
\end{tabular}

Pada tabel 1. terlihat bahwa, pada 85 orang sampel penelitian terdapat 1 orang $(1,2 \%)$ memiliki usia 18 tahun, 27 orang (31,8\%) memiliki usia 19 tahun, 55 orang (64,7\%) memiliki usia 20 tahun, serta 2 orang (2,4\%) dengan usia 21 tahun.

Tabel 2. Karakteristik Jenis Kelamin Sampel Penelitian

\begin{tabular}{ccc}
\hline Jenis Kelamin & Frekuensi $(\mathrm{n})$ & Persentase $(\%)$ \\
\hline Laki-laki & 26 & 30,6 \\
Perempuan & 59 & 69,4 \\
\hline Total & 85 & 100
\end{tabular}

Hasil analisis yang terdapat pada tabel 2. terdapat 26 orang $(30,6 \%)$ laki-laki, sedangkan perempuan sebanyak 59 orang $(69,4 \%)$ dari 85 orang yang menjadi subjek dalam penelitian ini.

Tabel 3. Distibusi Frekuensi Kualitas Tidur Sampel Penelitian

\begin{tabular}{ccc}
\hline Kualitas Tidur & Frekuensi $(\mathrm{n})$ & Persentase (\%) \\
\hline Baik & 33 & 38,8 \\
Buruk & 52 & 61,2 \\
\hline Total & 85 & 100 \\
\hline
\end{tabular}

Tabel 3. menggambarkan dari 85 orang mahasiswa yang menjadi sampel pada penelitian ini, mayoritas mahasiswa mengalami kualitas tidur yang buruk yakni 52 orang $(61,2 \%)$ dan terdapat 33 orang $(38,8 \%)$ mengalami kualitas tidur baik.

\begin{tabular}{ccc} 
Tabel 4. Distribusi & Frekuensi IMT Sampel Penelitian \\
\hline Kategori IMT & Frekuensi & Persentase (\%) \\
\hline Kurus & 10 & 11,8 \\
Normal & 33 & 38,8 \\
Berlebih & 42 & 49,4 \\
\hline Total & 85 & 100 \\
\hline
\end{tabular}

Data yang disajikan dalam tabel 4. menunjukan bahwa mayoritas mahasiswa di Fakultas Kedokteran Universitas Udayana yang menjadi sampel penelitian ini termasuk dalam kategori IMT berlebih yakni sebanyak 42 orang $(49,4 \%), 33$ orang $(38,8 \%)$ tergolong dalam kategori IMT normal dan terdapat 10 orang $(11,8 \%)$ tergolong dalam kategori IMT kurus.

Hasil analisis antara dua variabel yakni, variabel independen yaitu kualitas tidur serta IMT sebagai variabel dependen dengan analisis bivariat menggunakan uji chi-square disajikan pada tabel di bawah ini.

Tabel 5. Hubungan Kualitas Tidur dengan IMT

\begin{tabular}{|c|c|c|c|c|c|c|c|c|c|}
\hline \multirow{3}{*}{ Kualitas Tidur } & \multicolumn{6}{|c|}{ IMT } & \multirow{2}{*}{\multicolumn{2}{|c|}{ Total }} & \multirow{3}{*}{$\begin{array}{c}\text { Asymptotic Significance } \\
\text { (2-sided })\end{array}$} \\
\hline & \multicolumn{2}{|c|}{ Kurus } & \multicolumn{2}{|c|}{ Normal } & \multicolumn{2}{|c|}{ Berlebih } & & & \\
\hline & $\mathrm{N}$ & $\%$ & $\mathrm{~N}$ & $\%$ & $\mathrm{~N}$ & $\%$ & $\mathrm{n}$ & $\%$ & \\
\hline Buruk & 3 & 3,5 & 11 & 12,9 & 38 & 44,7 & 52 & 61,1 & \\
\hline Baik & 7 & 8,3 & 22 & 25,9 & 4 & 4,7 & 33 & 38,9 & \\
\hline Jumlah & 10 & 11,8 & 33 & 38,8 & 42 & 49,4 & 85 & 100 & \\
\hline
\end{tabular}

Pada tabel 5. terdapat nilai Asymp.Sig. (2-sided) sebesar 0,000 pada hasil chi-square. Nilai Asymp. Sig. (2sided) $<0,05$ memiliki makna yakni ada hubungan signifikan antara kualitas tidur dengan IMT pada mahasiswa di Fakultas Kedokteran Universitas Udayana. Sampel penelitian dominan mengalami kualitas tidur buruk yakni berjumlah 52 orang $(61,1 \%)$ dengan dominan sampel termasuk ke dalam kategori IMT berlebih yakni sebanyak 38 orang $(44,7 \%)$ sedangkan sebanyak 11 orang (12,9\%) termasuk kategori normal serta sebanyak 3 orang $(3,5 \%)$ merupakan sampel dengan kategori kurus. Mahasiswa dengan kualitas tidur tergolong baik didapatkan 33 orang $(38,9 \%)$ dari 85 orang yang merupakan sampel penelitian dengan mayoritas sampel tergolong dalam kategori IMT normal yakni sebanyak 22 orang $(25,9 \%)$, sebanyak 7 orang $(8,3 \%)$ termasuk kategori kurus, dan yang termasuk kategori berlebih sebanyak 4 orang $(4,7 \%)$.

Berdasarkan tabel 5. yakni ada hubungan antara kualitas tidur dengan IMT pada mahasiswa di Fakultas Kedokteran Universitas Udayana, yang mana sampel dengan kualitas tidur buruk dominan memiliki IMT berlebih dan sampel dengan kualitas tidur baik dominan memiliki IMT normal.

\section{DISKUSI \\ Karakteristik Sampel Penelitian}

Penelitian dilaksanakan di lingkungan Fakultas Kedokteran Universitas Udayana dengan mengambil sampel sebanyak 85 orang. Sampel tersebut telah memenuhi kriteria inklusi serta eksklusi dan telah terpilih secara acak dengan 
teknik sampling. Data yang dipergunakan yakni data primer yang merupakan hasil perhitungan skor dari kuesioner PSQI dan IMT pada sampel yang dilakukan sendiri oleh peneliti.

Hasil penelitian yang telah dilakukan memperoleh hasil antara lain sampel mayoritas berusia 20 tahun yakni dengan jumlah 55 orang (64,7\%) sedangkan sebanyak 27 orang (31,8\%) memiliki usia 19 tahun, 2 orang (2,4\%) memiliki usia 21 tahun, serta terdapat 1 orang $(1,2 \%)$ yang berusia 18 tahun. Mayoritas sampel adalah perempuan dengan jumlah 59 orang $(69,4 \%)$ dan laki-laki sebanyak 26 orang (30,6\%).

Hasil penelitian pada kualitas tidur menunjukkan bahwa kualitas tidur buruk dominan terjadi pada sampel yakni sebanyak 52 orang $(61,2 \%)$ sedangkan sebanyak 33 orang (38,8\%) mengalami kualitas tidur baik. Hasil yang didapatkan serupa dengan penelitian Prayogo tahun 2018 pada mahasiswa keperawatan Fakultas Kedokteran dan IImu Kesehatan Universitas Muhammadiyah Yogyakarta dengan hasil sebagaian besar mahasiswa yang merupakan sampel penelitian memiliki kualitas tidur buruk sebesar 84,4\%. ${ }^{14}$ Penelitian yang sama di tahun 2019 juga dilakukan pada mahasiswa di Fakultas Kedokteran Universitas Andalas oleh Ulfa, didapatkan pula hasil yakni mayoritas mahasiswa $(67,61 \%)$ tergolong dalam kualitas tidur buruk. ${ }^{15}$ Penelitian mengenai kualitas tidur buruk juga dilakukan pada mahasiswa kedokteran yakni di Hongkong, didapatkan sebesar $70 \%$ mahasiswa mengalami kualitas tidur buruk. Hal yang sering dikaitkan dengan terjadinya kualitas tidur buruk pada mahasiswa kedokteran antara lain durasi belajar yang panjang, intensitas belajar yang tinggi, serta gaya hidup. ${ }^{6}$

Hasil perhitungan IMT ditemukan bahwa mayoritas mahasiswa tergolong dalam kategori IMT berlebih sesuai dengan klasifikasi IMT berdasarkan Depkes RI dengan nilai IMT $\geq 25,0$ yakni sebanyak 42 orang (49,4\%), sedangkan sebanyak 33 orang (38,8\%) tergolong dalam kategori IMT normal dengan nilai IMT $\geq 18,5-<24,9$ serta terdapat 10 orang (11,8\%) tergolong dalam kategori IMT kurus dengan nilai IMT < 18,5. Kemajuan teknologi yang terjadi saat ini, menyebabkan individu cenderung menghindari kegiatan yang membutuhkan energi lebih banyak seperti kegiatankegiatan yang bersifat manual. Kendaraan bermotor lebih banyak digunakan dibandingkan dengan sepeda atau bahkan jalan kaki, selain itu perilaku sedentary life yang berkaitan dengan penggunaan internet dan komputer dijadikan sebagai gaya hidup belakangan ini. ${ }^{16}$

Kondisi tersebut diperburuk dengan perilaku mengonsumsi makanan siap saji maupun makanan cepat saji yang memiliki kualitas gizi yang buruk yakni karbohidrat serta lemak yang terkandung cukup tinggi namun sedikit mengandung vitamin dan mineral. ${ }^{17}$ Densitas energi lebih tinggi ditemukan pada makanan siap saji (ready prepared food) dan makanan cepat saji (fast food) dibandingkan rnakanan tradisional. Hal tersebut mengakibatkan tubuh menerima energi secara berlebihan apabila mengonsumsi makanan jenis tersebut. Faktor aktivitas fisik serta asupan makanan memegang peranan penting dalam proses terjadinya overweight dan obesitas. ${ }^{16}$

\section{Hubungan antara Kualitas Tidur dengan IMT}

Nilai p 0,000 didapatkan pada hasil analisis hubungan antara kualitas tidur dan IMT, nilai $p<0,05$ memiliki simpulan bahwa pada penelitian ini $\mathrm{HO}$ ditolak dan Ha diterima. Hasil tersebut mengandung arti bahwa, ada hubungan antara kualitas tidur dengan IMT pada mahasiswa di Fakultas Kedokteran Universitas Udayana. Pada tabel 5 terlihat bahwa dominan sampel mengalami kualitas tidur buruk $(61,1 \%)$ dan dominan memiliki IMT berlebih $(44,7 \%)$ dengan nilai IMT $\geq 25,0$, sedangkan sampel yang mengalami kualitas tidur baik didapatkan 33 orang (38,9\%) dan dominan memiliki IMT normal (25,9\%) dengan nilai IMT $\geq 18,5-<24,9$. Berdasarkan hasil tersebut dapat ditarik simpulan bahwa ada hubungan antara kualitas tidur dengan IMT pada mahasiswa di Fakultas Kedokteran Universitas Udayana, yang mana sampel dengan kualitas tidur buruk dominan memiliki IMT berlebih, sedangkan sampel dengan kualitas tidur baik dominan memiliki IMT normal.

Hasil penelitian lain juga didapatkan nilai p 0,000 pada mahasiswa di Fakultas Kedokteran Universitas Andalas yang artinya terdapat hubungan antara kualitas tidur dan IMT pada tahun 2019 oleh Ulfa. ${ }^{15}$ Penelitian lain oleh Ryandra juga dilakukan pada mahasiswa di Fakultas Kedokteran Universitas Muhammadiyah Malang di tahun 2016 dan mendapatkan hasil yang serupa dengan nilai $p$ value $(0,000)$. Hasil tersebut menunjukkan bahwa antara kualitas tidur dan IMT berlebih pada mahasiswa terdapat hubungan. ${ }^{18}$ Penelitian pada mahasiswa di Fakultas Kedokteran Universitas Islam Indonesia memperoleh simpulan bahwa semakin buruk kualitas tidur mahasiswa maka nilai IMT serta persentase lemak pada tubuh akan semakin tinggi nilainya. Mahasiswa kedokteran yang memiliki tanggung jawab berat serta durasi mengenyam pendidikan yang panjang akan semakin rentan mengalami stres dan kecemasan yang kemudian hal tersebut akan berdampak pada kualitas tidur mereka. ${ }^{7}$

Durasi tidur merupakan salah satu dari tujuh komponen yang digunakan dalam menilai kualitas tidur individu, sehingga durasi tidur yang kurang akan mempengaruhi kualitas tidur seseorang. ${ }^{4}$ Penurunan jam tidur juga dikaitkan dengan beberapa perubahan fisiologis seperti peningkatan kadar kortisol dan ghrelin, penurunan kadar leptin dan gangguan metabolisme glukosa. ${ }^{9}$ Ghrelin berperan dalam meningkatkan nafsu makan dan menurunkan pemakaian cadangan lemak. Penurunan jam tidur pada seseorang dapat menyebabkan terstimulasinya ghrelin, sehingga nafsu makan meningkat dan pemakaian cadangan lemak semakin menurun. ${ }^{10}$ Sebaliknya, penurunan jam tidur akan menurunkan kadar leptin yang menyebabkan nafsu makan sulit untuk dihambat dan menurunnya rangsangan pengeluaran energi. Hal ini dikarenakan leptin berperan mengatur massa jaringan lemak dan berat badan dengan cara menghambat asupan makanan dan merangsang pengeluaran energi. ${ }^{11}$

Peningkatan kadar kortisol berpengaruh pada metabolisme glukosa pada orang dengan penurunan jam tidur. Salah satu peran dari kortisol yakni menurunkan kadar insulin dan meningkatkan glukagon. ${ }^{19}$ Insulin bekerja mengambil glukosa yang beredar di pembuluh darah dengan cara merangsang sel-sel pada tubuh, kemudian mengubahnya sehingga dapat digunakan sebagai energi atau menyimpannya dalam bentuk glikogen pada hati dan otot. Sebaliknya, fungsi dari glukagon yakni memberi rangsangan pada sel hati serta sel otot untuk mengubah glikogen yang disimpan menjadi bentuk glukosa, kemudian glukosa tersebut diedarkan kembali ke pembuluh darah. Penurunan kadar insulin dan peningkatan kadar glukagon menyebabkan kadar glukosa dalam darah meningkat. ${ }^{20}$ 
Obesitas dan kegemukan merupakan masalah kesehatan yang mempertinggi risiko kejadian penyakit noninfeksi antara lain kardiovaskular, diabetes melitus, atau bakan penyakit kanker yang berdasarkan data WHO memiliki angka kematian dua kali lipat lebih tinggi dari angka kematian akibat penyakit infeksi yakni sebanyak 65\% di seluruh dunia. ${ }^{13}$ Kondisi fisik seseorang juga dapat terpengaruh akibat kualitas tidur yang buruk. Seseorang dengan kualitas tidur buruk akan merasa kelelahan, kelelahan yang dialami menyebabkan seseorang tidak ingin melakukan aktivitas maupun olahraga. Dalam jangka waktu yang panjang apabila kualitas tidur yang buruk kemudian disertai pola hidup yang tidak sehat, dapat berdampak pada terjadinya peningkatan IMT yang akan berujung pada terjadinya obesitas. ${ }^{12}$ Kualitas tidur dapat dijadikan sebagai pertimbangan untuk mencapai keberhasilan dalam manajemen berat badan selain berfokus pada pola makan serta tingkat aktivitas fisik. ${ }^{13}$

\section{SIMPULAN}

Simpulan yang didapatkan dari hasil penelitian serta analisis menggunakan uji chi-square yakni ada hubungan antara kualitas tidur dengan IMT pada mahasiswa di Fakultas Kedokteran Universitas Udayana. Sampel dengan kualitas tidur buruk dominan memiliki IMT berlebih dengan nilai IMT $\geq 25,0$ dan sampel dengan kualitas tidur baik dominan memiliki IMT normal dengan nilai IMT $\geq 18,5-<24,9$.

\section{DAFTAR PUSTAKA}

1. Maharani K. Hubungan Kualitas dan Durasi Tidur terhadap Indeks Massa Tubuh dan Rasio Lingkar PinggangPanggul pada Mahasiswa Fakultas Kedokteran Universitas Gadjah Mada. [Skripsi]. Yogyakarta: Universitas Gajah Mada; 2016.

2. Nilifda H., Nadjmir and Hardisman. Hubungan Kualitas Tidur dengan Prestasi Akademik Mahasiswa Program Studi Pendidikan Dokter Angkatan 2010 FK Universitas Andalas. Jurnal Kesehatan Andalas. 2016; 5(1): $243-249$.

3. Sulistiyani C. Beberapa Faktor yang Berhubungan dengan Kualitas Tidur pada Mahasiswa Fakultas Kesehatan Masyarakat Universitas Diponegoro Semarang. Jurnal Kesehatan Masyarakat. 2012; 1(2): 280-292.

4. Wijayanti AT. Hubungan antara Kualitas Tidur dengan Tekanan Darah pada Perawat Kelas III di RSUD DR. R. Goetoeng Taroenadibrata Purbalingga Tahun 2017. [Skripsi]. Purwokerto: Universitas Muhammadiyah Purwokerto; 2017.

5. Sharma A., Dixit AM., Krishnappa K., Sharma R., Shukla, SK. and Jain PK. Comparative Study of Sleep Habits Among Medical and Non-medical Students in Saifai, Etawah. Int J Community Med Public Health. 2018; 5(9): 38763881.

6. Azad MC., Fraser K., Rumana N., Abdullah AF., Shahana N., Hanly PJ. and Turin TC. Sleep Disturbances among Medical Students: A Global Perspective. Journal of Clinical Sleep Medicine. 2015; 11(1): 69-74.

7. Ratri NW. Hubungan Kualitas Tidur terhadap Nilai Indeks Massa Tubuh dan Persentase Lemak Tubuh pada Mahasiswa Fakultas Kedokteran Universitas Islam Indonesia. [Skripsi]. Yogyakarta: Universitas Islam Indonesia; 2018.

8. Schmid SM., Hallschmid M., Jauchchara K., Born J. and Schultes B. A Single Night of Sleep Deprivation Increases Ghrelin Levels and Feelings of Hunger in Normal-weight Healthy Men. J. Sleep Res. 2008; 17: 331-334.

9. AIDabal L. and BaHammam AS. Metabolic, Endocrine, and Immune Consequences of Sleep Deprivation. The Open Respiratory Medicine Journal. 2011; 5: 31-43.

10. Meutia M. Peran Hormon Ghrelin dalam Meningkatkan Nafsu Makan. Medan: Universitas Sumatera Utara; 2005.

11. Subarjati A. Hubungan Indeks Massa Tubuh dengan Kadar Leptin dan Adiponektin. [Skripsi]. Semarang: Universitas Diponegoro; 2015.

12. Ganakin SV. Hubungan Kualitas Tidur dengan Kondisi Obesitas pada Mahasiswa Fakultas Kedokteran UKWMS. [Skripsi]. Surabaya: Universitas Katolik Widya Mandala Surabaya; 2017.

13. Tandy S. Hubungan Kualitas Tidur dengan Obesitas pada Mahasiswa Fakultas Kedokteran Universitas Sumatera Utara Angkatan 2014. [Skripsi]. Medan: Universitas Sumatera Utara; 2017.

14. Prayogo EB. Kualitas Tidur dengan Indeks Massa Tubuh pada Mahasiswa PSIK Tingkat Akhir. [Skripsi]. Yogyakarta: Universitas Muhammadiyah Yogyakarta; 2018.

15. Ulfa S. Hubungan Kualitas Tidur dengan Indeks Massa Tubuh pada Mahasiswa Fakultas Kedokteran Universitas Andalas Angkatan 2018. [Skripsi]. Padang: Universitas Andalas; 2019.

16. Ranggadwipa DD. and Murbawani EA. Hubungan Aktivitas Fisik dan Asupan Energi terhadap Massa Lemak Tubuh dan Lingkar Pinggang pada Mahasiswa Fakultas Kedokteran Universitas Diponegoro. [Skripsi]. Semarang: Universitas Diponegoro; 2014.

17. Utami NA. Hubungan Pola Makan dan Aktivitas Fisik terhadap Kejadian Overweight dan Obesitas pada Remaja. [Skripsi]. Semarang: Universitas Diponegoro; 2017.

18. Ryandra Y. Hubungan Kualitas Tidur dengan Indeks Massa Tubuh Berlebih pada Mahasiswa Fakultas Kedokteran Universitas Muhammadiyah Malang. [Skripsi]. Malang: Universitas Muhammadiyah Malang; 2016.

19. Thau L. and Sharma S. Physiology, Cortisol. [Internet] Available at: www.ncbi.nlm.nih.gov/books/NBK538239/. Diakses pada 29 Januari 2019.

20. Aeni A. Uji Efek Hipoglikemik Ekstrak Etanol Daun Kentut (Paederia Foetida L.) Berdasarkan Perbedaan Tempat Tumbuh Tanaman pada Mencit Galur Swiss Webster dengan Metode Toleransi Glukosa. [Skripsi]. Bandung: Universitas Islam Bandung; 2016. 